$4 \mid 1985$

Aspects des agricultures insolites de l'Amérique indienne

\title{
Les techniques indigènes de construction des champs artificiels dans la vallée de Mexico
}

\section{Teresa Rojas-Rabiela}

\section{(2) OpenEdition}

\section{Journals}

Édition électronique

URL : https://journals.openedition.org/tc/984

DOI : $10.4000 /$ tc. 984

ISSN : 1952-420X

Éditeur

Éditions de l'EHESS

Édition imprimée

Date de publication : 1 février 1985

ISSN : 0248-6016

Référence électronique

Teresa Rojas-Rabiela, « Les techniques indigènes de construction des champs artificiels dans la vallée de Mexico », Techniques \& Culture [En ligne], 4 | 1985, mis en ligne le 26 janvier 2006, consulté le 29 septembre 2022. URL : http://journals.openedition.org/tc/984 ; DOI : https://doi.org/10.4000/tc.984

Ce document a été généré automatiquement le 29 septembre 2022.

Tous droits réservés 
Les techniques indigènes de construction des champs artificiels dans la vallée de Mexico

Teresa Rojas-Rabiela 